\title{
Inventory and Resource Mapping of Fiber Yielding Plants in Mountain Province
}

\author{
Arel B. Sia-ed \\ Teacher Education Department \\ Mountain Province State Polytechnic College \\ Bontoc, Mountain Province, Philippines
}

\begin{abstract}
Fiber crops are industrial field crops grown for their fibers which are valuable in the manufacture of paper, cloth, rope and textile products. In the Philippines, the major fiber crops as identified by the Fiber Industry Development Authority (FIDA) include abaca, silk and pina. In Mountain Province, the villagers use the fibers from indigenous crops in the hinterland in tying animals, bundling firewood and palay, and as clotheslines. The study was conducted to catalogue the fiber yielding plants in Mountain Province and to identify the specific areas where this grow. Descriptive research design using inventory, survey and mapping was utilized in the study. Preliminary consultation with the Municipal Agricultural Offices was conducted and validation was coordinated with the DENR-ERDS in Loacan, Baguio City Philippines. Findings show that there are eighteen fiber yielding plants in the province. Fibers may occur in almost any part of a plant: stems, leaves, fruits, seeds, or roots and are classified as trees, herbs, shrubs, and ferns. Majority of the fiber yielding plants are found in Western Mountain Province and they thrive in forests and mountains. Moreover, there are eleven families of the fiber yielding plants, majority of which belong to the family moraceae. These fiber yielding plants are recommended to be grown and propagated in the different municipalities of Mountain Province. Lastly, training on management of the fiber yielding plants should be conducted to add knowledge and ensure greater yield and quality produce.
\end{abstract}

Keywords: Fiber Yielding Plants, Inventory, Mapping, Mountain Province

\section{Introduction}

Fiber crops are industrial field crops which are important in the manufacture of paper, cloth, rope and textile products. In the Philippines, with the great variety of plants, it is not surprising to find a large number which produce useful fibers. The fiber crops industry is one of the major pillars in the economy in the generation of employment and foreign exchange. The lead agency for the industry is the Fiber Industry Development Authority (FIDA) that spearheads the production of the major fiber crops that includes abaca, silk and pina. Next to food, clothing and shelter represent the primary necessities of life. The early human beings made their garments from the skins of animals, but the need of some form of clothing lighter and cooler than skins and hides changed man's attention to the use of plant and animal fibers. The use of fibers is not limited to clothing, but also in the production of raw materials just like cordage, ropes, bagging, canvass, tires, upholstery and others.

The Fiber Industry Development Authority (FIDA) announced the International Year of the Fibers in 2009. Activities for the event include setting of fiber-based products in trade fairs throughout the country and a fashion show titled "Weaves of the World" among others. Thus, researches on the fibers are very important to promote the use of indigenous and locally available raw materials and to ease the country's serious lack of fiber.

Mountain Province, Philippines Formerly dubbed as " La Montanosa" by Spanish administrators for its mountainous terrain. The Province lies in the heart of the Grand Cordillera, known to be the Philippine's biggest and highest chain of mountains. In Mountain Province, most of the fibers are derived from wild plants which are used locally for making inferior grades of ropes or for other minor purposes. The villagers use the fibers from indigenous crops in the hinterland as a rope in tying animals and bundling firewood and palay, and as a clothesline. With the vast resources in Mountain Province, ethno botany inventory and resource mapping is needed to collect baseline scientific data for R\&D and for designing and implementing ecological projects. Many studies have been done on the ethno botany of medicinal, indigenous vegetables and other useful plants in Mountain Province but, except for abaca, other fiber-yielding plants in Mountain Province was not given attention. 


\section{Methodology \\ Design and Locale of the Study}

This study utilized descriptive research design using inventory, survey and mapping approaches. The study areas are the ten municipalities of Mountain Province: Western Mountain Province which is comprised of Bauko, Tadian, Sabangan, Sagada, Besao, and Eastern Mountain Province comprising Sadanga, Bontoc, Barlig, Natonin and Paracelis. The Cordillera Administrative Region of the Philippines is located at the northern section where Mountain Province is among the six (6) provinces. Its capital town is Bontoc. Mountain Province is located at the cental part of the Cordilleras. The province was created in in 1908 with seven sub-provinces. It became an independent province on March 25, 1967. On April 7, 1967, the new Mountain Province got into operation. Just like any other provinces, Mountain Province is blessed with many natural resources that attracts so many tourists. Mummy caves, which contain naturally mummified bodies, hanging coffins, caves, water falls, blue mountains and many more attracts tourists to visit the province. The Province total land area is 209,733 hectares, $23 \%$ of which were classified as alienable and disposable, and $77 \%$ as forest lands. Impressively high mountain and sharp ridges are the common landscape of the central and western Mountain Province while gradually sloping and rolling foothills are the landscape of the eastern part.

\section{Data Gathering Procedures}

Preliminary consultation with the Municipal Agriculture Offices was conducted to present the project's rationale and objectives and to inquire about the existence of the fiber-yielding crops in the different municipalities and to identify the specific areas where the crops grow.

Actual field visits and survey were done in the identified areas. Data gathering tools such as semi-structured interview schedule, direct observations, focus group discussion, and photo documentation were done to obtain information. Participatory Rural Appraisal was used to characterize and assess local community resources especially fiber crops. Further validation of the identified fiber yielding plants was coordinated with the Department of Environment and Natural Resources - Environment and Research Development Service (DENR ERDS) in Loacan, Baguio City, Philippines.

\section{Results and Discussion}

\section{Catalogue of the Fiber Yielding Plants in Mountain Province}

There are eighteen (18) identified fiber yielding plants in Mountain Province. The identified plants are classified as trees, shrubs, herbs and ferns. These were the sources of ropes used by the villagers before and were commonly used to tie firewood from the mountains, palay from the fields and animals. Four (4) of these: abaca, banana, maguey and pineapple were proven and published by the Philippine Textile Research Institute (PTRI) and Fiber Industry Development Authority (FIDA) as potential fiber yielding plants. Extracted fibers from maguey and pineapple were also used by the villagers during the ancient time as clothes but were reported to be rough and itchy. The other fiber yielding plants were taken from the testimonies of respondents that they have been extracting and using them during the ancient times. They used it as yarn and were processed to produce ropes, mats, blankets and clothes. Further, four of these identified fiber yielding plants tallabing, ballay, bagengey, and balili are commonly made into fiber crafts like bags, baskets, and fish nets. Aside from using these products in their own homes they also sell it in the market. Thus the products from these fiber yielding plants also serves as their source of income for the family.

Table 1. Catalogue of the Fiber Yielding Plants in Mountain Province

\begin{tabular}{|l|l|l|l|}
\hline \multicolumn{1}{|c|}{$\begin{array}{c}\text { Fiber } \\
\text { Plants }\end{array}$} & \multicolumn{1}{|c|}{$\begin{array}{c}\text { Type of } \\
\text { Plant }\end{array}$} & \multicolumn{1}{|c|}{ Habitat } & \multicolumn{1}{c|}{$\begin{array}{c}\text { Location in Mountain } \\
\text { Province }\end{array}$} \\
\hline Abaca & Tree & Mossy Forest & Natonin, Barlig, Paracelis \\
\hline Agayen & Tree & Forest & Western Mountain Province \\
\hline Akbab & Shrub & Rainforest & $\begin{array}{l}\text { Eastern \& Western Mountain } \\
\text { Province }\end{array}$ \\
\hline Alen - ey & Tree & Rainforest & Western Mountain Province \\
\hline
\end{tabular}




\begin{tabular}{|l|l|l|l|}
\hline Apas & Shrub & Forest \& Mountains & Western Mountain Province \\
\hline Bagbago & Shrub & Forest \& Mountains & Western Mountain Province \\
\hline Baguingey & Fern & $\begin{array}{l}\text { Forest edges \& } \\
\text { Mountainous terrains }\end{array}$ & Western Mountain Province \\
\hline Balili & Fern & $\begin{array}{l}\text { Forest edges \& } \\
\text { Mountainous terrains }\end{array}$ & Western Mountain Province \\
\hline Ballay & Herb & Forest \& Mountains & $\begin{array}{l}\text { Eastern \& Western Mountain } \\
\text { Province }\end{array}$ \\
\hline Banana & Tree & Tropical regions & $\begin{array}{l}\text { Eastern \& Western Mountain } \\
\text { Province }\end{array}$ \\
\hline Chayoni & Shrub & Forest \& Mountains & Western Mountain Province \\
\hline Gumamela & Shrub & Tropical region & $\begin{array}{l}\text { Eastern \& Western Mountain } \\
\text { Province }\end{array}$ \\
\hline Kuba & Tree & Forest \& Mountains & Western Mountain Province \\
\hline Labso & Tree & Forest \& Mountains & Western Mountain Province \\
\hline Lafey & Tree & Forest \& Mountains & $\begin{array}{l}\text { Eastern \& Western Mountain } \\
\text { Province }\end{array}$ \\
\hline Maguey & Herb & Forest \& Mountains & Western Mountain Province \\
\hline Pina & Herb & Sub - tropic countries & $\begin{array}{l}\text { Eastern \& Western Mountain } \\
\text { Province }\end{array}$ \\
\hline Tallabing & Fern & $\begin{array}{l}\text { Forest edges \& } \\
\text { Mountainous terrains } \\
\text { Province }\end{array}$ \\
\hline
\end{tabular}

There are eleven (11) families of fiber yielding plants identified in Mountain Province. Majority of the identified fiber yielding plants belong to the family of moraceae. Accordingly, the moraceae species are good sources of fibers as claimed by Ms. Marilou Andrada of the DENR - ERDS. With over 1,000 species and 40 genera, this family is one of the more recognizable forest species in tropical areas (Wikipedia Encyclopedia). The other family of fiber yielding plants identified are Musaceae, Zingerabeaceae, Ruscaceae, Malvaceae, Amaryllidaceae, Bromeliaceae, Dipeteraceae, Poaceae, Euphorbiaceae, and Gunneraceae.

Table II. Taxonomical Classification of the Fiber Yielding Plant

\begin{tabular}{|l|l|l|l|l|}
\hline \multirow{2}{*}{$\begin{array}{c}\text { Fiber } \\
\text { Plants }\end{array}$} & \multicolumn{1}{|c|}{ Family } & \multicolumn{1}{c|}{ Scientific Name } & \multicolumn{1}{c|}{ English Name } & $\begin{array}{c}\text { Common } \\
\text { Name }\end{array}$ \\
\cline { 2 - 5 } & Musaceae & Musa textiles Nee & Manila Hemp & Abaca \\
\hline Abaca & Moraceae & Ficus microcopa & Curtain fig & Binonga \\
\hline Akbab & Zingiberaceae & $\begin{array}{l}\text { Leptosalena } \\
\text { haenkei }\end{array}$ & Mauritius Hemp & $\begin{array}{l}\text { Kamamar, } \\
\text { Panawil, } \\
\text { Garay }\end{array}$ \\
\hline Alen-ey & Moraceae & Ficus citrifolia & Banyan tree & Alen-ey \\
\hline Apas & Moraceae & Ficus irisana & Hayata fig & Apas \\
\hline Bagbago & Euphorbiaceae & Macaranga tanarilus & Hairy mahang & $\begin{array}{l}\text { Bagbago/ } \\
\text { Ninunga/ } \\
\text { Kuyonon }\end{array}$ \\
\hline Bagengey & Dipteraceae & $\begin{array}{l}\text { Diccranopteris } \\
\text { linearis }\end{array}$ & $\begin{array}{l}\text { Savannah fern, } \\
\text { false Staghorn } \\
\text { fern }\end{array}$ & Kilob \\
\hline Ballay & Gunneraceae & $\begin{array}{l}\text { Gunnera } \\
\text { macrophylla }\end{array}$ & $\begin{array}{l}\text { Giant rhubarb/ } \\
\text { Gunnera }\end{array}$ & Balai \\
\hline Balili & Poaceae & $\begin{array}{l}\text { Pasparum } \\
\text { scrubiculatom }\end{array}$ & Water sedge & Balbalili \\
\hline
\end{tabular}




\begin{tabular}{|l|l|l|l|l|}
\hline Banana & Musaceae & Musa paradisiaca & Banana & $\begin{array}{l}\text { Saging/Sa } \\
\text { ba }\end{array}$ \\
\hline Chayoni & Ruscaceae & Dracaena surculosa & $\begin{array}{l}\text { Spotted Dracaena/ } \\
\text { Gold Dust } \\
\text { Dracaena/ Gold } \\
\text { Dust Plant }\end{array}$ & Chayoni \\
\hline Gumamela & Malvaceae & $\begin{array}{l}\text { Hibiscus rosa } \\
\text { sinensis }\end{array}$ & Gumamela & $\begin{array}{l}\text { Gumamel } \\
\text { a, } \\
\text { Tangaya }\end{array}$ \\
\hline Kuba & Moraceae & Ficus stipulosa & Rubber tree & Pospos \\
\hline Labso & Moraceae & Ficus macrophylla & $\begin{array}{l}\text { Black fig/ Lord } \\
\text { Howe Island } \\
\text { banyan }\end{array}$ & Ladso \\
\hline Lafey & Moraceae & Ficus benguetensis & Host fig & Tibig \\
\hline Maguey & $\begin{array}{l}\text { Amaryllidacea } \\
\text { e }\end{array}$ & Agave cantala & Maguey or pulque & Maguey \\
\hline Piň a & Bromeliaceae & Ananas comosus & Pineapple & Pinya \\
\hline Tallabing & Dipteraceae & Dipteris conjugata & Broad leaf fern & Tallabing \\
\hline
\end{tabular}

\section{Mapping of Fiber Yielding Plants in Mountain Province}

Abaca grows in the wild in Natonin and some barangays (villages) in Paracelis and Barlig, making Mountain Province the only abaca-growing area in Northern Luzon (Northern Dispatch- Lyn V. Ramo). Natonin farmers grow abaca in almost 900 hectares of their land. The high cost of production is one problem abaca grower's face. Although abaca fiber production has potential in the Eastern part of Mountain Province especially in the municipality of Natonin due to the natural growing plants, local farmers have yet to benefit from it, owing to the low technical know-how among the villagers. It was found out that most abaca strippers are not locals of Natonin but from the Bicol region. In the study conducted, majority of the fiber yielding plants are found in Western Mountain Province. There are eight (8) plants found dominantly in Eastern Mountain Province and seventeen (17) are dominantly thriving in Western Mountain Province. Some fiber yielding plants inhabit both in the east and west but they were map in the place where they are dominantly found. All the identified plants thrive naturally and are available in forests and mountains of Mountain Province

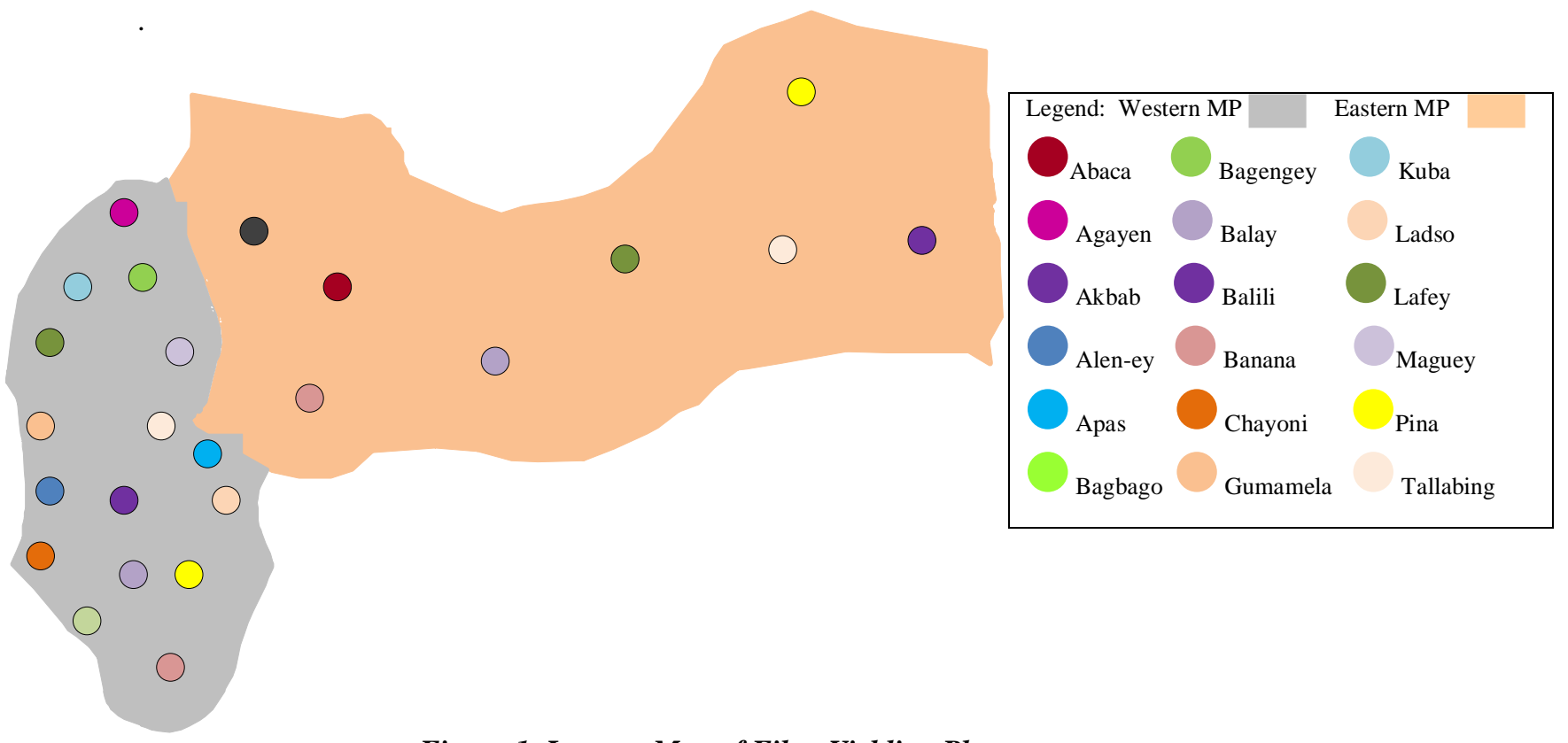

Figure 1. Locator Map of Fiber Yielding Plants 


\section{Conclusions}

There are 18 identified endemic plants available in Mountain Province which are potential sources of fibers. These include herbaceous plants, ferns and trees but majority are trees with the barks serving as the main sources of fibers. All of these are endemic, that is, they are naturally growing and are still available especially in the forests and mountains of Mountain Province. There are eleven (11) families of fiber yielding plants identified in Mountain Province. Majority of the identified fiber yielding plants belong to the family of moraceae. Abaca thrives most in Natonin and some villages of Paracelis and Barlig. Majority of the fiber yielding plants are found in Western Mountain Province. There are eight (8) plants found dominantly in Eastern Mountain Province and seventeen (17) are dominantly found in Western Mountain Province. All thriving naturally in the forests and mountain of the province.

\section{References}

[1] Fiber Industry Development Authority. Philippine Natural Fibers. Department of Agriculture. Quezon City, Philippines, 2004

[2] Pandey, Anjula \& Gupta, Rita. Fiber yielding plant of India: Genetics resources, perspective collection and utilization. National Product Radiance Vol. 2 (4) 194-204, 2003.

[3] Province of Mountain Province Official Website. (2018). Geography. (Online). Available: http://mountainprovince.gov.ph/geography/

[4] Singh, Kaushal K. Indian Himalayan region: some promising fiber yielding plants. G.B. Pant Institute of Himalayan Environment \& Development, Kosi-Katarmal, Uttarakhand, 2010.

\section{Appendices}

\section{Fiber Plants}
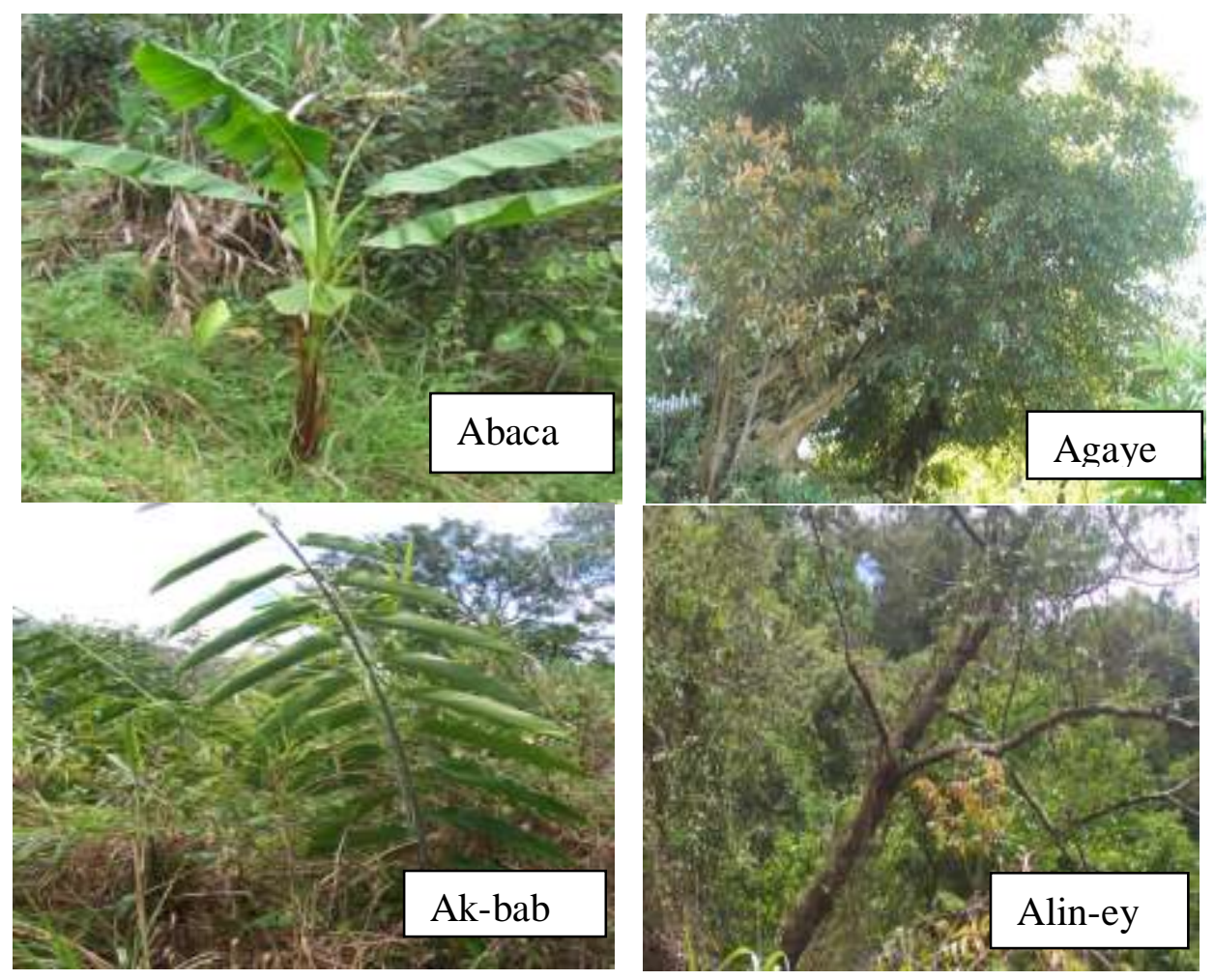


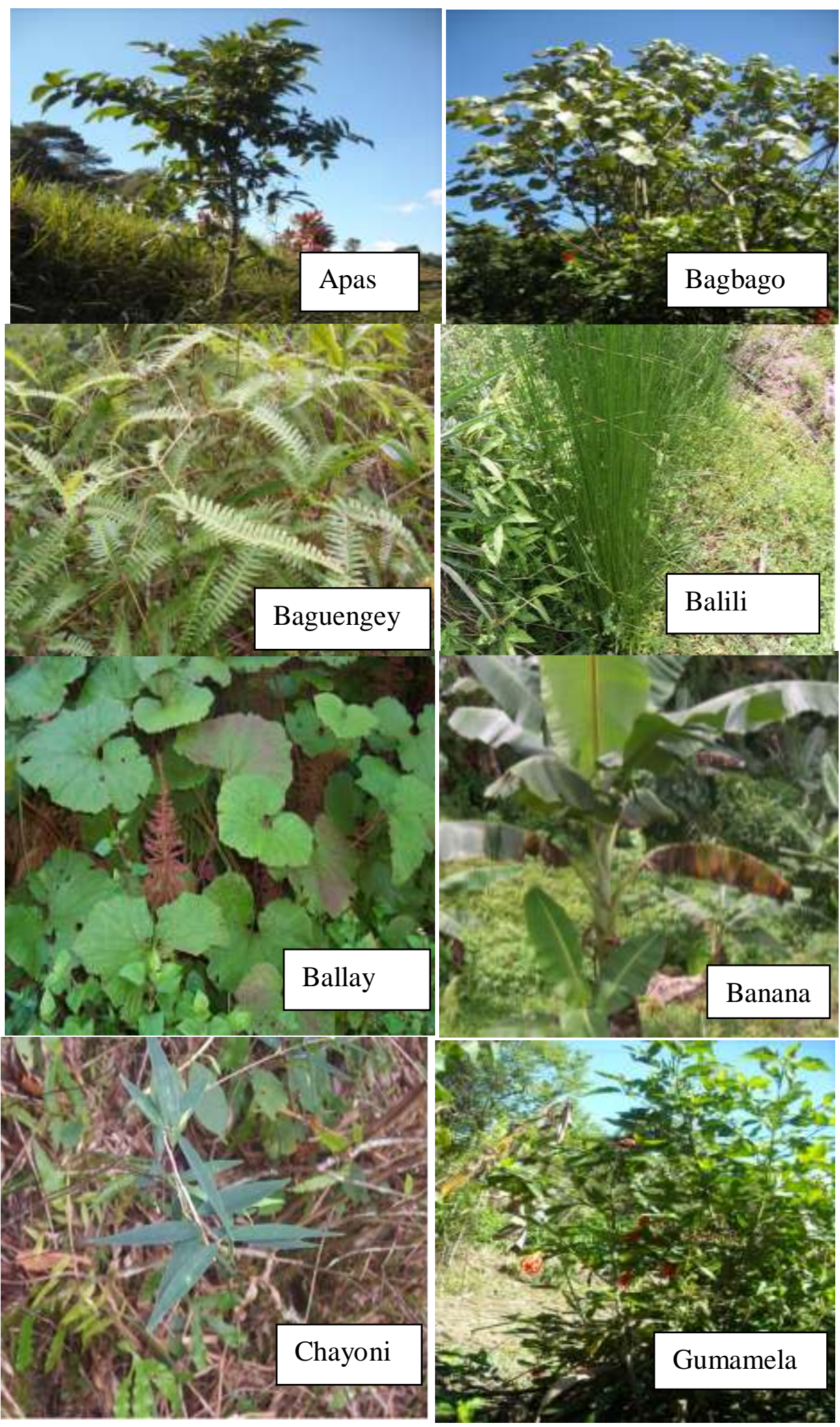




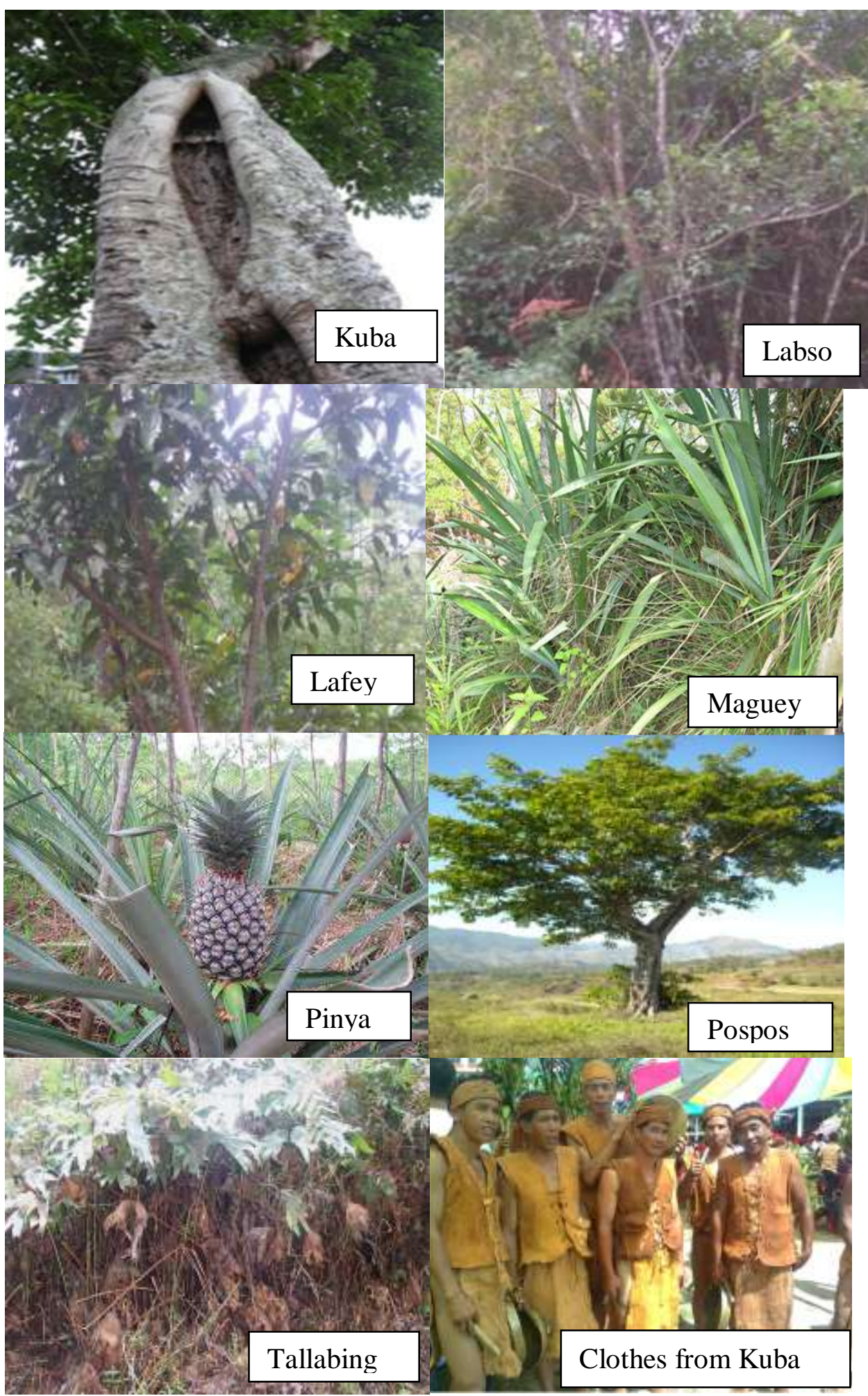




\section{Extracted Fibers}

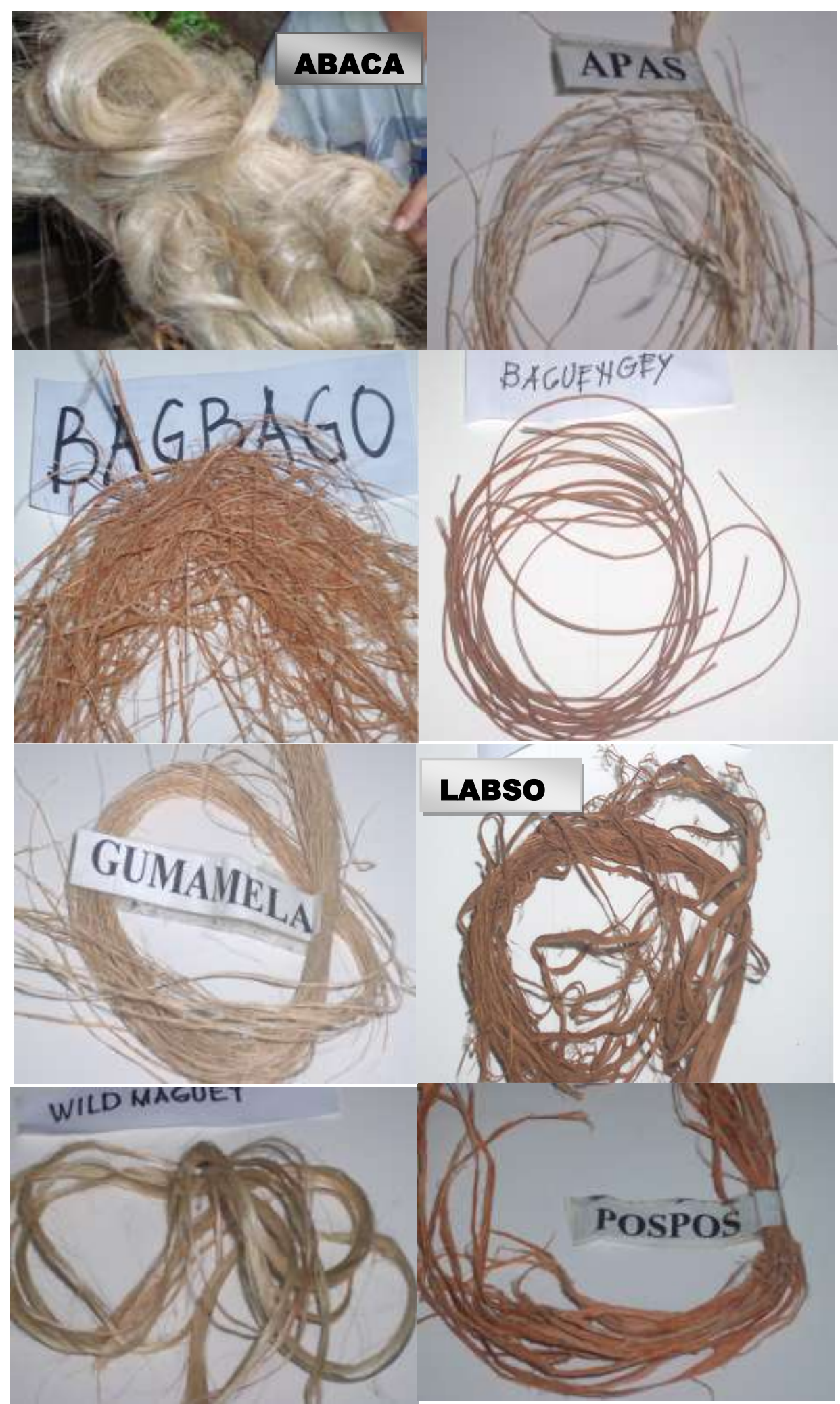

